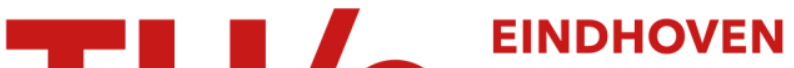

\section{High pressure check valve for application in a miniature cryogenic sorption cooler}

\section{Citation for published version (APA):}

Burger, J. F., Wekken, Van der, M. C., Berenschot, E. J. W., Holland, H. J., Brake, ter, H. J. M., Rogalla, H., Gardeniers, J. G. E., \& Elwenspoek, M. C. (1999). High pressure check valve for application in a miniature cryogenic sorption cooler. In Proceedings of the IEEE Micro Electro Mechanical Systems (MEMS), 17-21 Jan 1999, Orlando, FL, USA (pp. 183-188). Institute of Electrical and Electronics Engineers.

https://doi.org/10.1109/MEMSYS.1999.746803

DOI:

10.1109/MEMSYS.1999.746803

Document status and date:

Published: 01/01/1999

\section{Document Version:}

Publisher's PDF, also known as Version of Record (includes final page, issue and volume numbers)

\section{Please check the document version of this publication:}

- A submitted manuscript is the version of the article upon submission and before peer-review. There can be important differences between the submitted version and the official published version of record. People interested in the research are advised to contact the author for the final version of the publication, or visit the $\mathrm{DOI}$ to the publisher's website.

- The final author version and the galley proof are versions of the publication after peer review.

- The final published version features the final layout of the paper including the volume, issue and page numbers.

Link to publication

\section{General rights}

Copyright and moral rights for the publications made accessible in the public portal are retained by the authors and/or other copyright owners and it is a condition of accessing publications that users recognise and abide by the legal requirements associated with these rights.

- Users may download and print one copy of any publication from the public portal for the purpose of private study or research.

- You may not further distribute the material or use it for any profit-making activity or commercial gain

- You may freely distribute the URL identifying the publication in the public portal.

If the publication is distributed under the terms of Article 25fa of the Dutch Copyright Act, indicated by the "Taverne" license above, please follow below link for the End User Agreement:

www.tue.nl/taverne

Take down policy

If you believe that this document breaches copyright please contact us at:

openaccess@tue.nl

providing details and we will investigate your claim. 


\title{
HIGH PRESSURE CHECK VALVE FOR APPLICATION IN A MINIATURE CRYOGENIC SORPTION COOLER
}

\author{
J.F. Burger, M.C. van der Wekken, E. Berenschot, H.J. Holland, H.J.M. ter Brake, \\ H. Rogalla, J.G.E. Gardeniers and M. Elwenspoek \\ MESA Research Institute, University of Twente, The Netherlands \\ E-mail:J.F.Burger@tn.utwente.nl; Tel: X-31-53-4894423
}

\begin{abstract}
- This paper presents a check valve with integrated filter that can stand gas pressures of more than 100 bar in the closed direction and which has a very low pressure drop at low absolute gas pressures in the forward direction. The check valve is designed as a part of a check valve unit for application in a miniature cooler for cryogenic temperatures $(<120 \mathrm{~K})$. This cooling system, which utilizes several micromachined components, will in this paper be introduced to the MEMS field.
\end{abstract}

\section{Introduction}

Cryogenic coolers are refrigerators cooling to temperatures between nearly zero and $120 \mathrm{~K}$. There is a broad range of coolers available in terms of size, cooling power and operating temperature. Large and medium sized systems with up to some $\mathrm{kW}$ 's of cooling power are being used on a large scale for the liquefaction of gases. Many different types of somewhat smaller coolers exist, for instance in cryopumps or for cooling a wide range of detectors, low temperature and superconducting electronics. Cooling powers of such coolers typically range from 1 to $100 \mathrm{~W}$ for temperatures between 2 and $80 \mathrm{~K}$ [1].

During the last ten years a rapid development has taken place of LT-electronics and especially of superconducting devices. However, there exists a gap between this development and the availability of enabling technologies that are essential for the commercialization of LT-electronics [2]. These enabling technologies are low-cost, highly reliable cryogenic refrigeration systems and energy-efficient cryogenic packaging of the LT-electronic device with the cryogenic refrigerators. Much effort is currently put in the development of such reliable and cheap coolers, but the smallest systems are still reasonably large in terms of size $(>1 \mathrm{~kg})$ and cooling power $(>1 \mathrm{~W})$. Low temperature applications requiring very little cooling power, such as a single chip with a low noise amplifier or a superconducting magnetometer, would benefit from very small closed-cycle coolers. Such coolers do not exist and in this respect it was suggested [3] that micromachining techniques can be attractive for miniature cooler components, such as heat exchangers, check valves or compressors. This paper presents a check valve unit for application in a miniature sorption cooler. This cooling system, which utilizes several micromechanical components, will in this paper be introduced to the MEMS field.
The cooling cycle was selected from a number of cooling concepts that are suitable to reach cryogenic temperatures. Both the Stirling-like and vapor compression cycles are candidates for research towards miniaturized cooler components $[1,5,6]$. For both cycles it is essential to find a suitable, small, energy efficient and reliable compression principle. In our microcooling project we have chosen to focus on a vapor compression cycle driven by a so called sorption compressor, aiming at a cooling power of $10-50 \mathrm{~mW}$ at $80 \mathrm{~K}$. The advantage of this cycle is the absence of wear-related moving parts, except for some check valves. This facilitates scaling down of the system to very small sizes, it minimizes electromagnetic and mechanical interference (which is important for many applications), and it offers the potential of a long lifetime. The sorption cooler, described in the next section, is designed as a hybrid system containing both micromachined and precision-engineered components. Technology choices will be explained as well.

\section{Miniature sorption cooler}

A sorption cooler consists of a compressor unit, a counterflow heat exchanger, and a Joule-Thomson expansion valve, see figure 1 . The compressor unit generates a DC flow of gas that is isothermally compressed in the Van der Waals regime, thus reducing the internal energy of the fluid. The

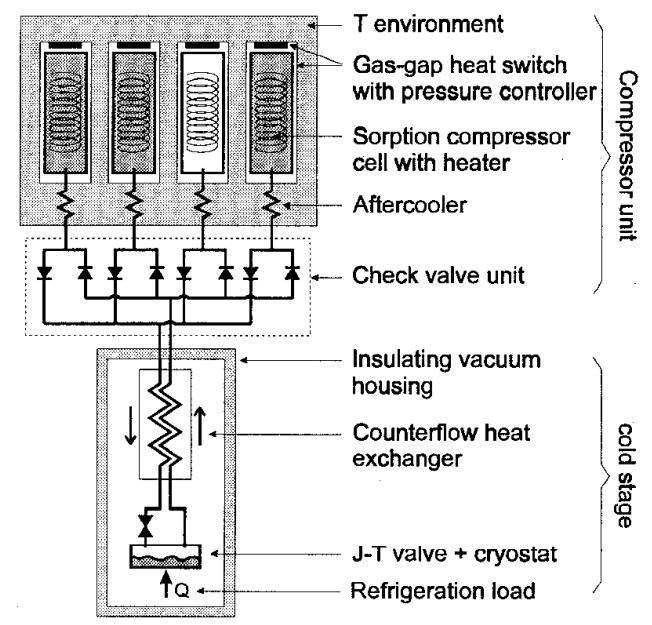

Figure 1. Sorption cooler set-up. 
(a)

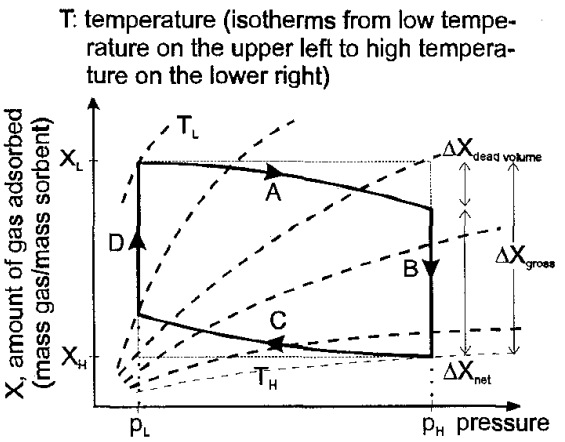

(b)

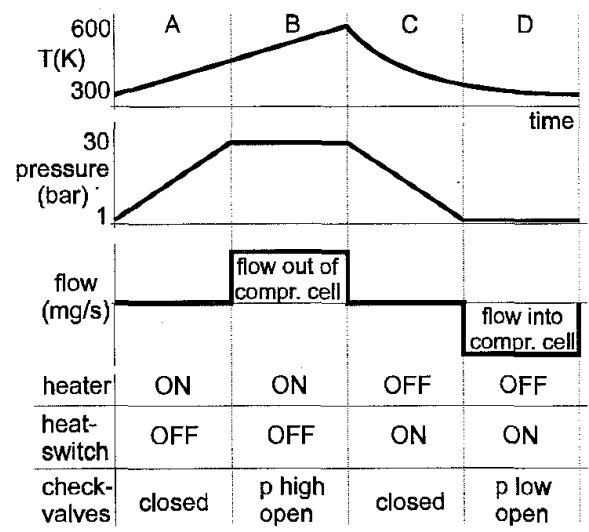

Figure 2. Schematic of compressor cycle in adsorption diagram with isotherms (a) and as a function of time (b).

compressed fluid coming out of the compressor moves through the counterflow heat exchanger to the cold side where Joule Thomson (JT) expansion to low pressure occurs through a restriction, requiring heat from the environment to increase the internal energy of the fluid [1]. The low-pressure refrigerant then returns through the counterflow heat exchanger to the compressor unit. In this way the heat exchanger facilitates effective precooling of the high-pressure gas using the returning cold low-pressure gas. The 'cold stage' is packaged in a vacuum container to minimize conductive heat losses.

The compressor unit contains four sorption cells and several check valves to control the gas flows. Low and high pressures are generated by the cyclic ad- and desorption of a working gas on a sorption material, which is accomplished by cooling and heating of the sorption material. The gas can either be physically adsorbed onto or chemically absorbed into various solids. Usually, heating occurs with an electrical heater and cooling is done with a heat-switch between the sorption cell and a heat sink on the outside. Figure 1 shows a configuration with a gas-gap heat switch around the cylinders. Adjusting the gas pressure in the gap can vary the heat conduction through the gap. If hydrogen gas is used for this, the pressure can be controlled using a miniature or thin-film metal-hydride pressure controller [7].

A compressor cycle of one cell is schematically shown in figure 2. The cell is heated during sections $A$ and $B$, and cooled during $C$ and $D$. During sections $A$ and $C$ both valves of the cell are closed, and the cell is in a regenerating phase. During sections $B$ and $D$ one of the valves is opened; the cell generates a high pressure gas flow out of the cell during $B$, and a low pressure gas flow into the cell during D. It is important to notice that the valves are passive check valves; the cycle is driven by the temperature induced pressure variations of the compressor cells. In our case a complete compressor cycle typically takes about 2 minutes.

A thermodynamic analysis of sorption coolers was presented elsewhere [8]. In that analysis the Coefficient of Performance (COP) of the compressor and cold stage were modelled separately, both for quasi-static conditions ${ }^{1}$. From the parameter study it followed that the compressor performance strongly depends on the sorption material, the gas, the compressor material, and the temperatures and pressures the compressor operates on. Microporous activated carbon with a high internal surface area was chosen as sorption material for a first demonstrator cooler, in combination with xenon as a refrigerant gas that is able to cool to $165 \mathrm{~K}$. For a low pressure of 1 bar an optimum compressor performance was found for compression to 10-20 bar and compressor cells operating between 300 and $600 \mathrm{~K}$. However, it appeared that the cold stage required somewhat higher pressures ( $>60$ bar) to perform well. It was shown that slightly precooling of the gas by means of a miniature thermoelectric cooler connected somewhere halfway the counterflow heat exchanger results in a dramatic improvement of the performance at a pressure of 20 bar, resulting in an overall cooler performance of about $4 \%$. We aim at a cooling power of $400 \mathrm{~mW}$, requiring an input power of about $12.5 \mathrm{~W}$ and a Xe massflow of about $5 \mathrm{mg} / \mathrm{s}$. These mentioned parameters define the requirements for the individual cooler elements. The cooler stage can be used as a single stage cooler, or as a precooling stage for a second sorption cooler operating with nitrogen gas cooling to $75 \mathrm{~K}$.

The compressor unit is constructed of four modular compressor cells made of stainless steel 316. Machining is mainly done by laser cutting and welding techniques. The cells can be operated without adjustable heat switch, resulting in a reduced performance [7]. However, a micromachined metalhydride pressure controller is currently under study. The cells measure $\phi 1 \times 10 \mathrm{~cm}$ with a wall thickness of $200 \mu \mathrm{m}$, and will finally be scaled to $\phi 0.5 \times 5 \mathrm{~cm}$. The cold stage can be constructed using either micromachining or alternative techniques, or by a combination of both. A miniature cold stage made out of capillary glass tubes was recently demonstrated [9]. Little [10] has shown the feasibility of a cold stage made out of channels that were 'etched' in glass plates using sandblasting and gluing techniques. A combination of both techniques for the construction of the cold stage is currently under investigation.

The check valves that are presented in this paper were developed because no commercial valves could be found that fulfilled the requirements of the cooler. Micromachining techniques were chosen for this development because of some

\footnotetext{
${ }^{1}$ In general, the COP of some kind of process is defined as the ratio of the useful energy that comes available and the energy that is required for that. In the case of a cooler, it is the ratio of the cooling power and the required input power.
} 
significant advantages compared to precision engineering techniques:

- Accurate construction of the valve and small spring elements is possible

- A nearly perfect valve seal is possible using the flatness of a polished wafer surface. This is required because of the very small leakage flow that is allowed when the valve is closed. Clean processing of the valves is also essential for a proper seal. Clean processing is inherent to MEMS techniques.

- Integration of eight valves in one unit becomes really straightforward. Dead volumes deteriorating the compressor performance can be kept very small.

- Integration of $\mu \mathrm{m}$-sized sieves in the design is possible to trap contamination that could cause leakage of the valve.

\section{Check valve design}

Requirements. The requirements for the check valves are given in table 1 . They are derived from the cooler parameter settings as given in the previous section.

In fact, the check valves connected to the high-pressure line of the cold stage have different requirements than the ones connected to the low-pressure line. In closed direction, the requirements are the same. Both valves have to stand periodically pressure differences up to the maximum pressure difference of 20 bar. A maximum pressure difference of 50 bar is required for testing purposes. Gas leakage in the closed direction is a loss factor and should be kept below a small fraction of the normal gas flow in forward direction $(<1 \%)$. The valve should close immediately as soon as the pressure difference reverses. Consequently, the valve should be normally closed but without a significant spring force to reduce the pressure drop in forward direction.

In forward direction, the massflows through both valves are the same but the absolute gas pressures and densities are a factor of 20 different. In both cases the pressure drop should be a small fraction of the absolute pressure. By designing a check valve that fulfills this requirement for the low-pressure gas, the same valve will certainly also fulfill the requirements for the high-pressure gas.

From experiments with a large scale sorption cooler it appeared that leaking check valves (of a commercial type) were the major cause of malfunction of the system [11]. This was explained by contamination of the valve seat. From this we concluded that prevention of possible contamination is a major requirement.

Because of the relatively long compressor cycling period, dynamic properties are not really a design issue.

Table 1. Requirements for the check valve.

\begin{tabular}{|l|l|}
\hline Forward direction: & Closed direction: \\
\hline $\begin{array}{l}\text { absolute gas pressure: } \cong 1 \mathrm{bar} \\
\text { xenon gas flow: } \cong 5 \mathrm{mg} / \mathrm{s} \\
\text { pressure drop: }<20 \mathrm{mbar}\end{array}$ & pressure difference: $50 \mathrm{bar}$ \\
gas leakage: $<50 \mu \mathrm{g} / \mathrm{s}$
\end{tabular}

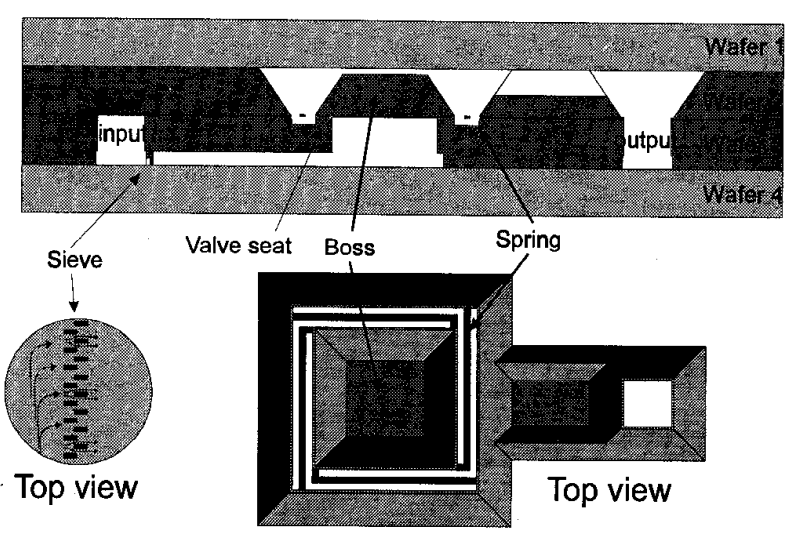

Figure 3. Design impression of the high-pressure check valve. Spring dimensions (height $x$ width $\times$ length): $10 \times 50 \times 1200$ um; boss: $1 \times 1 \mathrm{~mm}$.

Design. A design impression of the check valve is given in figure 3 . The valve consists of a thick plate (boss) suspended by four thin springs. The thin springs behave like single clamped beams, thus facilitating high deflections which are required to obtain a low pressure drop in the forward direction. When the valve is in forward direction, the gas is able to flow through the holes surrounding the springs. The entire valve construction, including the interfacing gas lines, is made out of two silicon wafers that are covered by two glass wafers. The design is such that the gas lines on both sides of the valve can cross in the upper and lower wafer. This is required for the construction of an integrated unit of eight valves that has only six connections to the outside world: four to the compressor cells and two to the cold stage.

The valve seat is made out of the polished surface of the wafers, facilitating a perfect fit and alignment of both sides of the valve seat. Stiction of the fragile spring beams to the bottom wafer is prevented by etching a cavity in the bottom wafer under the beams. Stiction or bonding of the valve seat is prevented by application of a nitride coating. The maximum allowed deflection of the boss can be selected by choosing an appropriate thickness of the boss relative to the wafer thickness.

A $4 \mu \mathrm{m}$ sieve is constructed in the inflow line of the valve to trap possible contamination. The sieve is made of a row of pillars standing in the channel.

Modelling and parameter choice. Fluidic and mechanical modelling was applied to find the proper dimensions of the valve construction. Governing equations can be formulated for the situation that the valve is closed and for the situation that it is in forward direction. For both situations a sketch of the valve with relevant parameters is given in figure 4.

When the valve is closed and a large pressure difference is present, stresses in the construction are the major parameters that have to be adjusted to safe values. To get a good seal, the valve seat is designed such that high pressures and stresses are present in the seat, but they should be limited to safe values. Under the condition that a uniform stress is present in the 


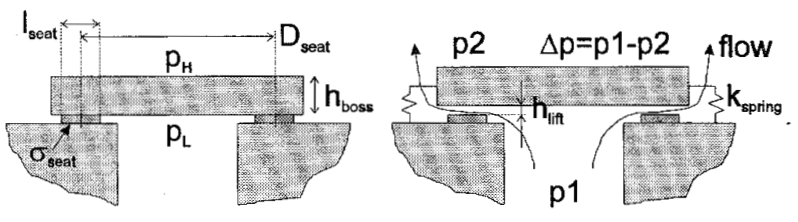

Figure 4. Sketch of valve in closed and forward situation.

circular seat, and also $D_{\text {sect }} \gg l_{\text {seat }}$ and $p_{H} \gg p_{L}$, this stress can be approximated by:

$$
\sigma_{\text {seat }}=p_{H} \frac{D_{\text {seat }}}{4 \cdot l_{\text {seat }}}
$$

Other possible critical stresses that should be limited are bending stresses in the covering glass wafers and in the boss.

When the valve is in the forward direction, the fluid flow over the valve seat is certainly in the laminar flow regime. If entrance effects are neglected, the pressure drop can then be given by the Bernoulli equation. By using expressions for the friction factor, the Reynolds number, the gas velocity, and geometric factors, the pressure drop can be expressed as:

$$
\Delta p=\frac{12 \mu l_{\text {seat }} \dot{m}}{\pi \rho D_{\text {seat }} h_{\text {lift }}{ }^{3}}
$$

where $\mu$ is the dynamic viscosity and $\rho$ the density of the gas, $\dot{m}$ is the massflow and the other parameters are as defined in figure 4. This pressure drop is balanced by the spring construction with spring constant $k_{\text {spring: }}$ :

$$
k_{\text {spring }}=\frac{4 E b_{\text {spring }} h_{\text {spring }}{ }^{3}}{l_{\text {spring }}{ }^{3}}
$$

where $b_{\text {spring, }} h_{\text {spring }}$ and $l_{\text {spring }}$ are the width, thickness and length of the springs and $E$ is the Young's modulus of silicon. The balance results in a lift of:

$$
h_{\text {lift }}=\frac{\pi D_{\text {seat }}^{2}}{4 k_{\text {spring }}} \Delta p
$$

By combining equations (2) and (4), the pressure drop and lift can be expressed as follows:

$$
\Delta p=4\left(\frac{3}{\pi^{4}} \frac{\mu}{\rho} \frac{l_{\text {seat }} k_{\text {spring }}^{3}}{D_{\text {seat }}^{7}} \dot{m}\right)^{1 / 4}
$$

$$
h_{\text {lift }}=\left(3 \frac{\mu}{\rho} \frac{l_{\text {seat }} D_{\text {seat }}}{k_{\text {spring }}} \dot{m}\right)^{1 / 4}
$$

Another effect in forward direction of the valve is the bending stress that occurs in the springs. This stress, that should be limited to safe values as well, is given by:

$$
\sigma_{\text {max }, \text { spring }}=\frac{3 E h_{\text {spring }}}{l_{\text {spring }}^{2}} h_{l i f t}
$$

In order to find a logic path for the parameter choices, it is important to categorize the many parameters that are involved. They can be divided in fixed system and material properties (pressures, mass flow, Young's moduli, max. stresses), controllable dimensions $\left(D_{\text {seat }}, l_{\text {seat }}, h_{\text {boss }}\right.$ and spring dimensions), and dependent parameters that should be kept within certain limits (pressure drop, stress in the seat, boss deflection and stress, gas leakage, stress in springs, stress in glass cover).

In order to reduce the number of controllable parameters, equation (1) is used to relate $l_{\text {seat }}$ to $D_{\text {seat }}$ by choosing a certain stress $(50 \mathrm{Mpa})$ that should be present in the valve seat when it is closed with a pressure of $p_{\max }=50$ bar. Furthermore, the springs should preferably fit around the valve opening, see figure 3 . Therefore, $l_{\text {spring }}=1.25 \cdot D_{\text {seat }}$ was chosen. Now $D_{\text {seat }}$, $h_{\text {spring }}, b_{\text {spring }}$ and $h_{\text {boss }}$ can be varied within certain technology related boundaries, and $\Delta p, h_{\text {lift }}, \sigma_{\max , \text { spring }}, \sigma_{\max , \text { boss }}$ and $\sigma_{\max }$, glass can be calculated as a function of them. Figure 5 gives an example of $\Delta p, h_{\text {lift }}$ and $\sigma_{m a x, \text { spring }}$ as a function of $D_{\text {seat }}$ and $h_{\text {spring, }}$ which are the parameters that have the biggest impact on the behaviour.

It is required that $D_{\text {seat }}>500 \mu \mathrm{m}$ because of the $\mathrm{KOH}$ etching step that is used to create the boss. Furthermore, the fabrication scheme of the springs causes a non-uniformity of the spring thickness of several $\mu \mathrm{m}$ for springs on different locations on the wafer. This thickness should, therefore, be larger than $10 \mu \mathrm{m}$. By taking $D_{\text {seat }}=1 \mathrm{~mm}$ and $h_{\text {spring }}$ between 10 and $20 \mu \mathrm{m}$, the requirements are fulfilled. The space above the boss should be at least $25 \mu \mathrm{m}$ to prevent the boss from touching the Pyrex wafer.
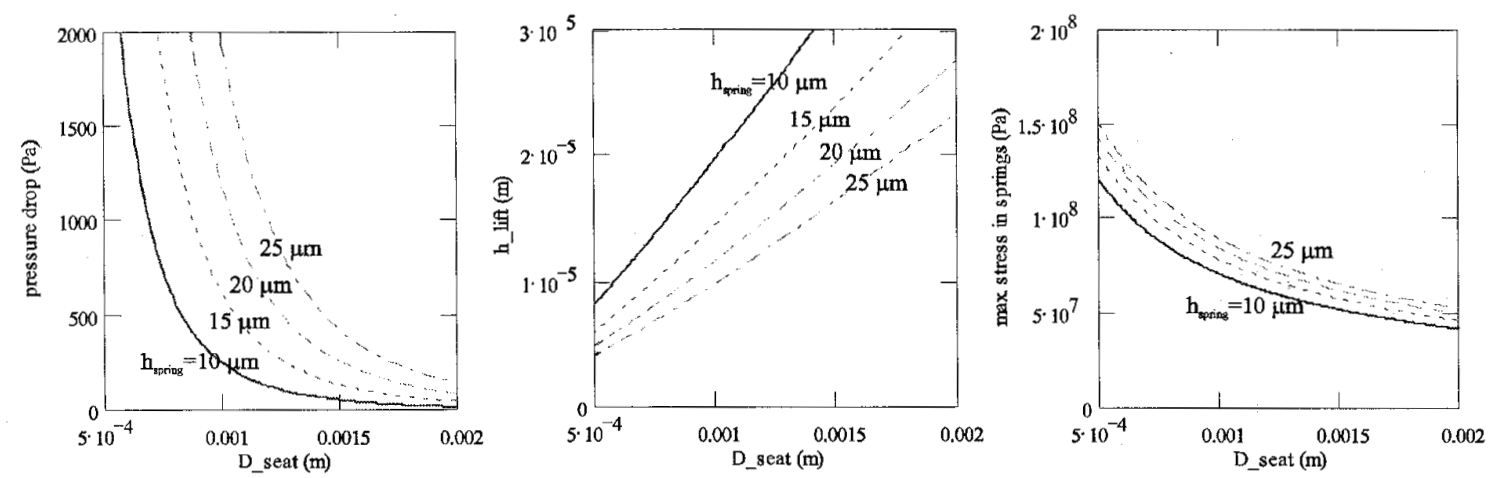

Figure 5. Pressure drop, lift and seat stress as a function of valve diameter and spring thickness. 
(a)

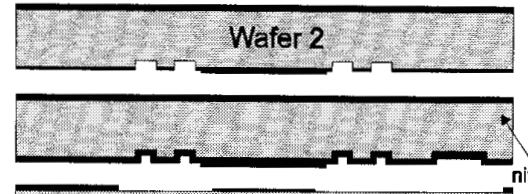

(c)

(d)
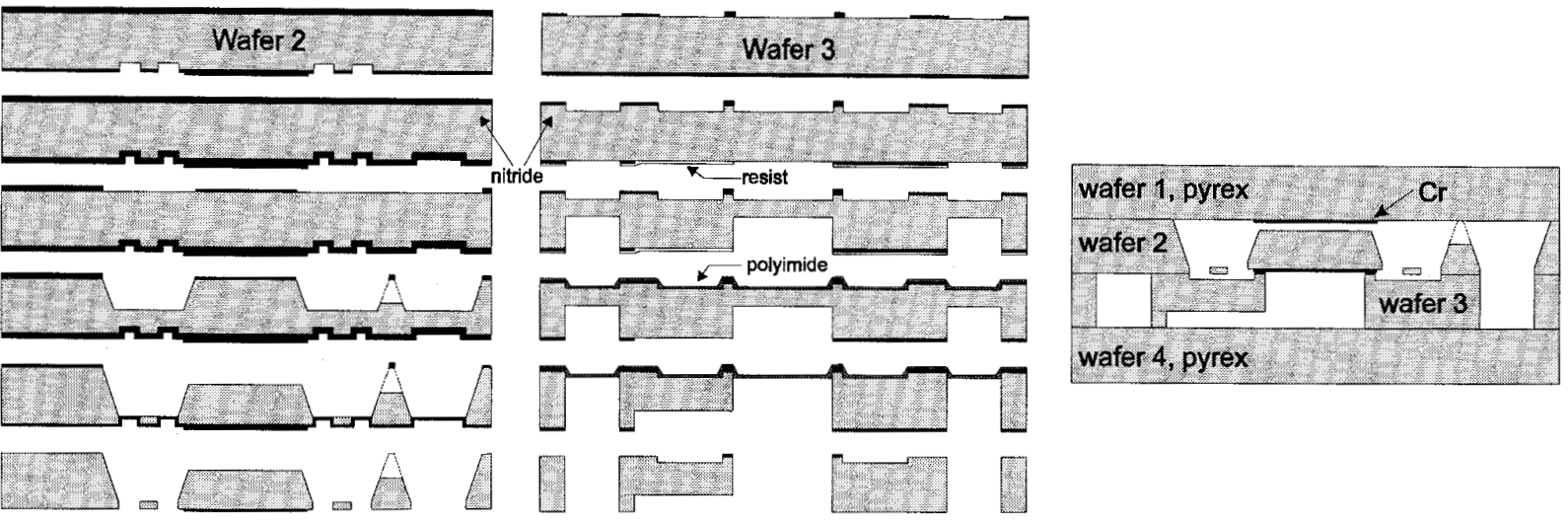

Figure 6. Processing scheme of the check valve.

\section{Fabrication}

Figure 6 shows some steps of the processing scheme of the check valve. The processing steps are such that the surfaces of wafer 2 and 3 that are used for the direct $\mathrm{Si}$-Si bond are covered with a protective nitride layer as much as possible to prevent degradation of the surface. Both wafers are double side polished wafers.

Wafer 2. (a) $1.0 \mu \mathrm{m}$ LPCVD nitride is grown and etched back to $0.5 \mu \mathrm{m}$ except at the backside of the boss that was patterned before. Next, the spring construction is patterned and etched to the desired thickness by means of RIE etching. (b) By means of $50 \% \mathrm{HF}$ etching $0.5 \mu \mathrm{m}$ nitride is etched away without mask, leaving only $0.5 \mu \mathrm{m}$ at the backside of the boss. Immediately after this step, $1.0 \mu \mathrm{m}$ nitride is grown. (c) On the topside the $\mathrm{KOH}$ mask is etched in the nitride, and after that the $1.0 \mu \mathrm{m}$ mask on top of the boss is thinned to $0.5 \mu \mathrm{m}$. This is a buried mask that can be freed after a period of $\mathrm{KOH}$ etching. The $\mathrm{KOH}$ mask includes a compensation structure. (d) $\mathrm{KOH}$ etching is done till approximately $25 \mu \mathrm{m}$ silicon is left on top of the spring construction. (e) $0.5 \mu \mathrm{m}$ nitride is etched away by means of $50 \% \mathrm{HF}$ etching. After this, the $\mathrm{KOH}$ etching is continued till the spring construction is etched through. During this step, the boss is thinned to the desired thickness. (f) Just prior to the bonding step, the nitride mask is removed using $50 \% \mathrm{HF}$ etching, leaving $0.5 \mu \mathrm{m}$ nitride on the bottom of the boss.

Wafer 3. (a) $1.0 \mu \mathrm{m}$ LPCVD nitride is grown. The valve seat is patterned and the nitride is etched to $0.5 \mu \mathrm{m}$ on both sides of the wafer. After that, the mask is made for the valve opening, the spring cavities and the connection tubes. (b) Cryogenic RIE etching is applied to etch $50 \mu \mathrm{m}$ into the wafer [12]. Next, the nitride on the backside is patterned and covered with a second resist mask as given in the picture. (c) $230 \mu \mathrm{m}$ cryogenic RIE etching is done at the backside of the wafer. (d) The resist is stripped and a polymer is applied on the frontside of the wafer to facilitate helium backside cooling during the last cryogenic RIE etching step through the wafer. During this step the pillar structure of the sieve is etched. (e) The polymer is stripped and just prior to the bonding step the nitride is removed using $50 \% \mathrm{HF}$ etching.

Bonding. Wafers 2 and 3 are connected using aligned direct wafer bonding techniques. Cleaning and chemical activation prior to bonding is essential [13]. The two wafers are annealed at $1100{ }^{\circ} \mathrm{C}$ in nitrogen ambient to enhance the bond strength. Finally, the wafers are covered with anodically bonded Pyrex wafers. On wafer 1 a thin chromium layer is applied at the location of the boss to prevent bonding of the boss to the glass [14]. Due to the applied electric field for the bonding step, the boss is capacitively pulled to the top wafer.

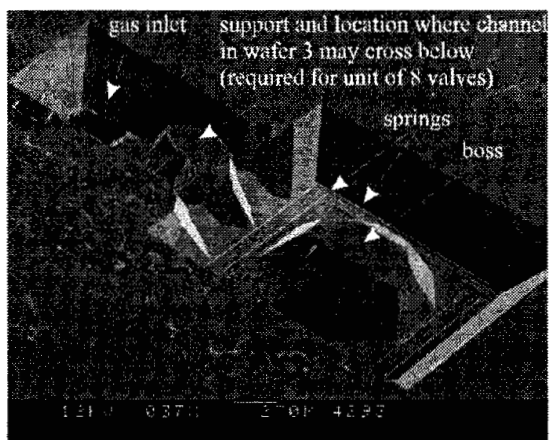

(a)

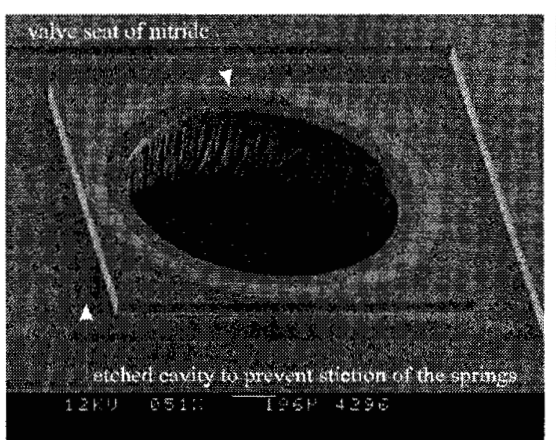

(b)

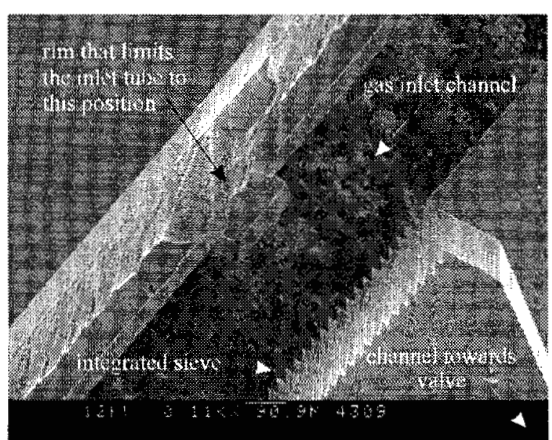

(c)

Figure 7: SEM pictures of (a) KOH etched boss; (b) the bottom wafer; (c) sieve in front of the inlet channel 
Interfacing. Sawing of the samples is done through wafers 1, 2 and 4, leaving the connection tubes in wafer 3 intact. This was done to prevent contamination of the tubes during dicing. Breaking the samples from the wafers cleanly opened the tubes. Connections to the outside world are made by fused silica tubes, which were glued in the channels.

Figure 7 shows four SEM pictures of different parts of the check valve.

\section{Characterization}

Experiments with samples bonded with $500 \mu \mathrm{m}$ Pyrex wafers showed that the valves could withstand pressures up to 65 bar in closed direction with a leakage flow that was not detectable $(<1 \mu \mathrm{g} / \mathrm{s})$. At higher pressures the glass wafer burst but the valve boss stayed intact. Samples bonded with thicker Pyrex wafers were tested up to 125 bar and did not burst at all.

With the valves in forward direction, measurements were done of the pressure drop as a function of the massflow. The set-up was constructed in such a way that the absolute pressure of the gas flow could be adjusted between 1.2 and 5 bar. Because the connecting tubes and the filter caused a major part of the pressure drop, measurements were also done with samples without boss in the valve. In this way the measurements could be corrected for these pressure drops. Figure 8 shows results for $p=2$ bar; measurements and theory agree quite well.

Small particles of $1-10 \mu \mathrm{m}$ were blown through a valve without integrated filter to test the influence of contamination on the closing behaviour of the valve. At $\Delta p=50$ bar a leakage flow was measured of $1.2 \mathrm{mg} / \mathrm{s}$. This indicates a significant leakage, but the valve did not break. Currently we are working on long duration experiments involving many forward/closed switching. First indications show an important function of the sieve in trapping of particles. The slightest contamination in samples without a sieve causes a significant leakage at higher pressures.

\section{Conclusions}

In conclusion we have shown high-pressure check valves with integrated 4-micron sieves. They are optimized for use in

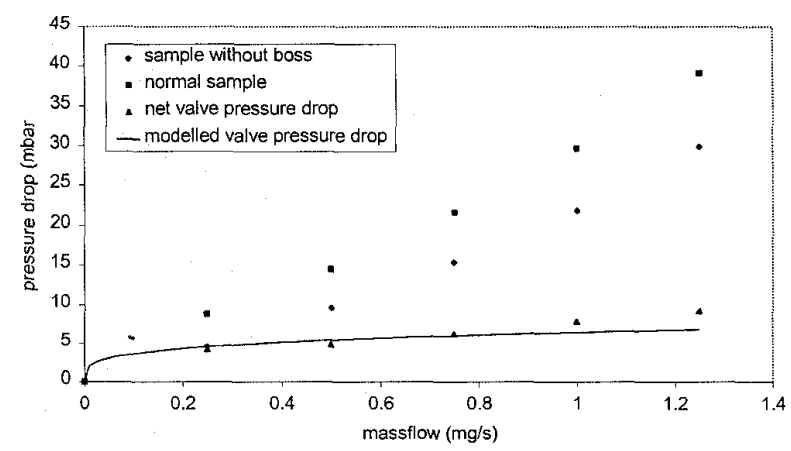

Figure 8. Pressure drop measurements of a valve in forward direction at a gas pressure of 2 bar. a microcooler and exhibit a very small flow resistance in the forward direction and a very small leakage at high pressures in the closed direction.

\section{Acknowledgments}

This research is supported by the Dutch Technology Foundation (STW). The authors would like to acknowledge the valuable contributions of Meint de Boer, who did much of the RIE etching.

\section{References}

[1] G. Walker, Cryocoolers, part 1: Fundamentals and part 2: Applications, Plenum Press, NY (1983).

[2] M. Nisenoff, 'Cryocoolers and High Temperature Superconductors: Advancing toward commercial applications', Cryocoolers 8, Plenum Press, NY (1995), pp. 913-917.

[3] G. Walker and R. Bingham, Micro and nano cryocoolers: speculation on future development, Proc. of the $6^{\text {th }}$ Int. Cryocooler Conf. (1990), pp. 363-375.

[4] L.A. Wade, An overview of the development of sorption refrigeration, Adv. in Cryogenic Eng. 37 (1992), pp. 1095-1106

[5] J.F Burger, H.J.M. ter Brake, M. Elwenspoek, H. Rogalla, Microcooling: Study on the application of micromechanical techniques, Cryocoolers 9, Plenum Press, New York (1997), pp. 687-696.

[6] L. Bowman, D.M. Berchowitz, I. Urieli, Microminiature Stirling cycle cryocoolers and engines, U.S. Patent 5457956 (1995)

[7] J.F. Burger, H.J. Holland, H. van Egmond, $M$. Elwenspoek, H.J.M. ter Brake, H. Rogalla, Fast gas-gap heat switch for a microcooler, Cryocoolers 10, Plenum Press, NY.

[8] J.F. Burger, H.J. Holland, L.A. Wade, H.J.M. ter Brake, H. Rogalla, Thermodynamic considerations on a microminiature sorption cooler, Cryocoolers 10, Plenum Press, NY.

[9] H.J. Holland, J.F. Burger, N. Boersma, H.J.M. ter Brake, H. Rogalla, Miniature 10-150 mW Linde-Hampson cooler with glass-tube heat exchanger operating with nitrogen.

[10] W.A. Little, Microminiature tefrigeration, Rev. Sci. Instrum. 55(5), 1984, pp. 661-680.

[11] S. Bard, J. Wu, P. Karlmann, C. Mirate, L. Wade, Component reliability testing of long-life sorption coolers, Proc. of the $6^{\text {th }}$ Int. Cryocooler Conf. (1990)

[12] H. Wensink, M.J. de Boer, R.J. Wiegerink, R.A.F. Zwijze, M. Elwenspoek, First micromachined silicon load cell for loads up to $1000 \mathrm{~kg}$, SPIE 98 (1998).

[13] C. Gui, Direct wafer bonding with chemical mechanical polishing, thesis, Twente University (1998).

[14] R.E. Oosterbroek, J.W. Berenschot, S. Schlautmann, T.S.J Lammerink, A. vanden Berg, M. Elwenspoek, Inplane oriented fluid control components, fabricated withnewetching techniques, Actuator' '98, pp. 43-46. 